Published by LPMP Imperium

Journal homepage: https:/ / ejournal.imperiuminstitute.org/index.php/ AKURASI

\section{Pengaruh Volume Perdagangan Saham, Leverage, dan Kebijakan Dividen Terhadap Volatilitas Harga Saham}

\section{Mario Ascaryo Septyadi, Theresia Hesti Bwarleling*}

Fakultas Ilmu Sosial dan Humaniora Universitas Bunda Mulia, Jakarta, Indonesia

\begin{abstract}
This study aims to determine the influence of Stock Trading Volume, Leverage, and Dividend Policy both simultaneously and partially from LQ45 Index companies listed on the Indonesia Stock Exchange in 2016-2018. The analysis technique used is multiple linear regression analysis using the IBM SPSS 26 program. This type of research is a quantitative study using secondary data, there are 18 companies as a sample of research data collected by purposive sampling technique. The dependent variable in this study is Stock Price Volatility, while the independent variables are Stock Trading Volume, Leverage, and Dividend Policy. The results showed that partially Stock Trading Volume has a positive and significant effect on Stock Price Volatility. Leverage and Dividend Policy have no significant effect on Stock Price Volatility. It is expected that the results of this study can be taken into consideration for investors to choose the right type of investment based on the level of stock price volatility that is influenced by various factors, especially stock trading volume.
\end{abstract}

Keywords:

Stock Trading Volume, Leverage, Dividend Policy, Stock Price Volatility

\section{Corresponding Author:}

Theresia Hesti Bwarleling, Universitas Bunda Mulia,

Jakarta, Indonesia.

Email: tbwarleling@bundamulia.ac.id

(c) The Author(s) 2020

DOI: https:/ / doi.org/ 10.36407/ akurasi.v2i3.251

\section{Research Paper}

Financial Management
Received: 15 Nov 2020

Revised: 10 Dec 2020

Accepted: 15 Dec 2020

Online: 30 Dec 2020

\title{
(CC)
}

CC BY: This license allows reusers to distribute, remix, adapt, and build upon the material in any medium or format, so long as attribution is given to the creator. The license allows for commercial use. 


\section{PENDAHULUAN}

Setiap perusahaan yang sukses, umumnya memerlukan modal yang cukup banyak dan biasanya mereka menarik dana modal tersebut dengan cara menerbitkan saham. Diharapkan dengan diterbitkannya saham, perusahaan tersebut dapat mencukupi kebutuhan modalnya yang dapat digunakan untuk pengembangan produk $(R \& D)$ ataupun untuk memperbesar perusahaannya dalam berbagai aspek, seperti gedung tempat produksi, memperbanyak toko distributor produk, membeli peralatan yang lebih canggih lagi, serta banyak hal yang perlu dilakukan untuk memajukan suatu perusahaan. Perusahaan-perusahaan ini akan menjadi faktor pendukung majunya suatu negara. Salah satu faktor utama yang diperlukan untuk merealisasikan hal tersebut adalah perolehan modal. Modal yang diperoleh dengan penerbitan saham, sehingga dapat dibeli oleh para investor, lebih baik daripada memperoleh modal dengan cara berhutang.Seperti yang telah diketahui bersama bahwa perolehan modal dari penjualan saham mengandung risiko yang lebih kecil.Namun, di sisi lain perlu juga diperhatikan bahwa pembelian saham oleh investor menandakan investor tersebut merupakan pemilik perusahaan, sehingga keberhasilan atau kegagalan perusahaan saat berkembang ditanggung bersama dengan investor.

Saham yang sudah diterbitkan, diharapkan dapat dibeli oleh para investor. Dalam melakukan suatu investasi, seorang investor biasanya akan menyiapkan beberapa pertimbangan terlebih dahulu sebelum melakukan keputusan investasinya baik itu mengenai kemampuan keuangan, return yang diharapkan, resiko yang akan dihadapi, dan jangka waktu investasi. Investasi merupakan penanaman dana pada satu atau lebih objek investasi yang dimiliki untuk mendapatkan keuntungan di masa yang akan datang (Reilly dan Brown, 2012). Dengan melakukan investasi itu berarti menunda konsumsi pada saat ini untuk mendapatkan keuntungan di masa yang akan datang. Investasi di pasar modal khususnya pada instrumen saham tentunya akan memberikan return dan risiko yang menarik (lebih besar) dibandingkan dengan instrumen-instrumen investasi lainnya.

Investasi didefinisikan sebagai komitmen atas sejumlah dana atau sumber daya lainnya yang dilakukan pada saat ini, dengan tujuan mendapat keuntungan di masa yang akan datang (Tandelilin, 2010:2). Ketika memutuskan untuk berinvestasi dalam bentuk saham, investor mengharapkan imbalan berupa pendapatan baik dalam bentuk dividend yield maupun capital gain.Dividend yield adalah arus kas yang dibayarkan secara periodik kepada pemegang saham (dalam bentuk dividen), sedangkan capital gain adalah keuntungan penjualan saham akibat selisih dari harga jual saham dengan harga belinya (Hartono, 2015:267).Investor biasanya menggunakan harga saham sebagai dasar pertimbangan karena nilai perusahaan dicerminkan oleh harga saham (Theresia dan Arilyn, 2015). Harga saham akan mengalami perubahan pada keadaan tertentu, tergantung pada kondisi pasar baik dari kinerja keuangan perusahaan yang menerbitkan saham maupun keinginan investor untuk membeli saham tersebut.

Volatilitas merupakan pengukuran statistik untuk fluktuasi harga selama periode tertentu.Ukuran tersebut menunjukkan penurunan dan peningkatan harga dalam jangka pendek. Disisi lain, volatilitas merupakan risiko sistematik yang dihadapi oleh investor yang melakukan investasi pada saham biasa. Volatilitas yang tinggi mencerminkan karakteristik permintaan dan penawaran yang tidak biasa.Saham yang memiliki tingkat volatilias yang tinggi cenderung memiliki jarak fluktuasi yang lebar, cepat naik dan cepat turun.Pergerakan perubahan harga saham yang sangat cepat mengindikasikan bahwa saham tersebut memiliki tingkat frekuensi perdagangan paling aktif yang dilakukan di pasar.Perubahan harga saham 
yang sangat fluktuatif mengindikasikan adanya suatu ketidakpastian atau yang biasa yang kita kenal dengan istilah "High Risk High Return". Semakin besar tingkat volatilitas harga saham maka return yang akan diperoleh dan risiko yang akan dihadapi juga semakin besar.

Faktor-faktor yang mempengaruhi volatilitas harga saham dikelompokkan ke dalam tiga kategori oleh Madura (2014), yaitu faktor ekonomi (faktor yang akan mempengaruhi cash flow perusahaan seperti pertumbuhan ekonomi, kebijakan pemerintah, tingkat suku bunga, nilai tukar mata uang asing dan inflasi), faktor pasar (sentimen investor dapat menyebabkan harga saham meningkat bahkan saat perekonomian sedang lemah karena investor mengharapkan perekonomian akan membaik di masa mendatang serta January effect juga berpengaruh terhadap harga saham karena banyak manajer portofolio memilih berinvestasi pada saham perusahaan kecil yang berisiko di awal tahun kemudian beralih kepada saham yang lebih stabil saat mendekati akhir tahun untuk memperoleh keuntungan), dan faktor internal perusahaan (pengumuman-pengumuman seperti kebijakan dividen, keputusan perusahaan untuk melakukan akuisisi dan divestasi, dan laporan keuangan perusahaan untuk melihat faktor fundamental perusahaan). Fahmi (2012:89), mengemukakan bahwa faktor-faktor yang dapat mempengaruhi volatilitas harga saham yaitu kondisi mikro dan makro ekonomi, kebijakan dalam memutuskan berekspansi, membuka kantor cabang, pergantian direksi, direksi perusahaan terlibat tindak pidana, kinerja perusahaan yang terus mengalami penurunan, risiko sistematis, dan efek psikologis dari pasar.

Penelitian ini menggunakan variabel volume perdagangan saham, leverage, dan kebijakan dividen.Kebijakan dividen merupakan keputusan perusahaan mengenai pembagian laba kepada pemegang saham sebagai dividen atau penahanan laba berupa laba ditahan untuk berinvestasi di masa datang ( Sartono, 2014:281).Kebijakan dividen merupakan salah satu petunjuk perusahaan yang dapat mengurangi perbedaan informasi mengenai kondisi dan prospek perusahaan antara manajemen perusahaan dan investor (Profilet dan Bacon, 2013). Informasi tentang kebijakan dividen akan memberikan sinyal mengenai prospek kinerja jangka panjang kepada investor sehingga investor berani menanamkan modalnya pada perusahaan. Kebijakan dividen merupakan salah satu faktor penting yang harus diperhatikan oleh manajemen dalam mengelola perusahaan karena memiliki pengaruh yang signifikan terhadap pihak perusahaan maupun pemegang saham. Bagi perusahaan, pembagian dividen akan mengurangi kas perusahaan sehingga dana yang tersedia untuk membiayai kegiatan operasi maupun reinvestasi akan berkurang. Bagi pemegang saham, dividen merupakan satu bentuk pengembalian atas investasi mereka.Kebijakan dividen diproksikan dengan dividend payout ratiodan dividend yield.Dividend payout ratio merupakan perbandingan antara dividen per lembar saham dengan laba per lembar saham.

Leverage adalah kemampuan perusahaan dalam memenuhi kewajiban jangka pendek maupun jangka panjang atau dengan kata lain mengukur seberapa besar perusahaan dibiayai dengan utang (Wiagustini, 2014:85). Leverage diproksikan dengan Debt to Equity Ratio (DER). Menurut Husnan dan Pudjiastuti (2012:72), debt to equityratio adalah rasio yang menunjukkan perbandingan antara utang dengan modal sendiri.Perusahaan dengan DER yang tinggi mencerminkan risiko keuangan yang dimiliki relatif tinggi karena perusahaan cenderung tergantung pada utang yang menyebabkan laba perusahaan berkurang karena kewajiban membayar utang beserta bunganya, dimana hal ini berdampak pada resiko investasi yang lebih tinggi (Harahap, 2009:303). Semakin tinggi DER, volatilitas harga saham 
akan meningkat karena perusahaan diasumsikan memiliki risiko yang tinggi terhadap likuiditas perusahaannya (Jannah dan Haridhi, 2016).

Volume perdagangan saham yaitu jumlah lembar saham yang diperdagangkan di pasar modal yang dapat menunjukkan reaksi pasar dari respon investor terhadap informasi yang masuk ke bursa. Oleh karena itu penulis tertarik untuk meneliti pengaruh volume perdagangan saham, leverage, dan kebijakan dividen terhadap volatilitas harga saham. Perusahaan yang diambil adalah perusahaan yang terdaftar dalam LQ45 di Bursa Efek Indonesia tahun 2016-2018. Perusahaan LQ45 dipilih karena saham-saham LQ45 merupakan saham-saham yang paling banyak diminati investor di pasar modal Indonesia, memiliki tingkat likuiditas tinggi atau yang aktif diperdagangkan di bursa, serta dijadikan sebagai patokan naik turunnya harga saham (IHSG) di Bursa Efek Indonesia.

\section{KAJIAN PUSTAKA}

\section{Teori Sinyal (Signalling Theory)}

Menurut Ross dalam Dewi (2019) signaling theory merupakan informasi terkait kondisi perusahaan yang dimiliki pihak eksekutif untuk disampaikan kepada calon investor. Teori ini menerangkan alasan mengapa perusahaan memiliki dorongan untuk menyerahkan laporan keuangan perusahaan kepada pihak eksternal. Perusahaan wajib mampu menghasilkan kas secukupnya dalam membayarkan dividen secara tunai, karena hal ini merupakan hal yang sangat mahal. Biaya pembayaran dividen dapat diganti melalui pengeluaran saham (Sari, 2019). Sementara menurut menurut Ouso dan Mustava (2018): "Signalling theory based on asymmetric information problems between well-informed managers and poorly informed outsiders. Corporate executives with favourable inside information about their firms have an incentive to convey this positive information to outside investors in order to cause an increase in the firm's stock price." Artinya adalah teori sinyal didasarkan pada asimetri informasi antara manajer perusahaan yang sangat tahu informasi mengenai perusahaan dengan orang dari luar perusahaan yang kurang tahu informasi mengenai perusahaan. Pihak eksekutif perusahaan memiliki informasi yang lebih baik tentang perusahaan mereka, memiliki insentif untuk menyampaikan informasi positif kepada investor luar agar saham perusahaan mengalami kenaikan.

\section{Teori Pecking Order (Pecking Order Theory)}

Menurut Myers (1984) dalam Ouso dan Mustava (2018), Teori Pecking Order adalah:

"Firms prefer internal financing to external financing of any sort, debt or equity. If a firm must obtain external financing, it will work down the Pecking Order of securities, beginning with very safe debt, then progressing through risky debt, convertible securities, preferred stock and finally stock as a last resort."

Arti dari kutipan tersebut adalah: "perusahaan lebih memilih pembiayaan internal daripada pembiayaan eksternal dalam bentuk apa pun, baik berupa utang ataupun ekuitas. Jika suatu perusahaan harus mendapatkan pembiayaan eksternal, hal itu akan dilakukan sesuai dengan Pecking Order, dimulai dengan utang yang sangat aman, kemudian berkembang melalui utang berisiko, sekuritas konversi, saham preferen dan akhirnya saham sebagai jalan terakhir." 
Berdasarkan kutipan tersebut, teori pecking order menyatakan bahwa perusahaan cenderung mencari sumber pendanaan yang minim risiko. Risiko yang dimaksud adalah menurunnya nilai perusahaan alias menurunnya harga saham. Teori pecking order lebih menyukai pendanaan dari internal perusahaan daripada eksternal perusahaan. Tidak ada struktur modal yang optimal dalam teori pecking order karena pemilihan pendanaan perusahaan didasarkan pada urutan hierarki risiko. Laba ditahan adalah opsi pertama yang akan dipilih perusahaan karena tidak berisiko atau memiliki risiko yang lebih kecil diantara opsi pendanaan yang lain. Laba ditahan adalah pendanaan internal yang diperoleh dari laba hasil operasional perusahaan diperiode sebelumnya. Apabila laba ditahan tidak mencukupi kebutuhan, opsi kedua adalah dengan pendanaan dari luar perusahaan, yaitu utang. Jika utang tidak bisa juga diperoleh, maka opsi terakhir adalah pendanaan dari ekuitas atau penerbitan saham baru. Pemegang saham menilai penerbitan saham baru lebih berisiko daripada utang.

\section{Pengaruh Volume Perdagangan Saham Terhadap Volatilitas Harga Saham}

Kondisi dari saham yang ditransaksikan di pasar modal akan berdampak pada harga saham dilihat dari volume perdagangannya (Andiani dan Gayatri, 2018). Teori sinyal atau signalling theory menyatakan bahwa investor merespon berbeda informasi dari perusahaan yang mampu mempengaruhi fluktuasi harga saham. Dimana volume perdagangan saham dapat menunjukkan reaksi pasar terhadap respon dari investor tersebut. Terdapat model yang menjelaskan volume perdagangan berhubungan dengan volatilitas. Asymmetric information model, yaitu investor melihat informasi privat dalam melakukan transaksi (Tim Studi Volatilitas Pasar Modal Indonesia dan Perekonomian Dunia, 2011). Dengan demikian informasi yang merupakan sinyal dari perusahaan dapat mempengaruhi volatilitas harga saham yang terlihat dari volume perdagangan atau seringnya saham tersebut diperjualbelikan pada bursa. Berdasarkan pernyataan tersebut maka dapat dirumuskan hipotesis sebagai berikut:

H1 : Volume perdagangan saham berpengaruh positif terhadap volatilitas harga saham.

\section{Pengaruh Leverage Terhadap Volatilitas Harga Saham}

Menurut (Fahmi, 2012:72) rasio leverage adalah suatu rasio untuk mengukur seberapa besar perusahaan dibiayai dengan utang. Untuk mengukur rasio leverage pada penelitian ini menggunakan debt to equity ratio. Debt to equity ratio digunakan untuk mengukur kemampuan perusahaan dalam menutupi sebagian atau seluruh utangnya baik jangka panjang maupun jangka pendek yang berasal dari modal sendiri, sehingga rasio ini akan mempengaruhi harga saham perusahaan.

Semakin tinggi DER mencerminkan risiko perusahaan relatif tinggi karena perusahaan dalam operasi cenderung tergantung terhadap utang dan perusahaan memiliki kewajiban untuk membayar bunga utang yang mengakibatkan laba perusahaan berkurang. Tetapi disisi lain, investor lebih tidak suka dengan perusahaan yang memperoleh modal yang berasal dari penerbitan saham baru. Hal ini mencerminkan bahwa perusahaan tidak mampu memperoleh pinjaman modal dari pihak kreditur. Hal ini menjadi sinyal buruk bagi para investor, dan akan berdampak pada berkurangnya tingkat kepercayaan investor terhadap perusahaan, yang mengakibatkan meningkatnya volatilitas harga saham. Sesuai dengan teori pecking order bahwa perusahaan lebih memilih memperoleh modal dari internal perusahaan. Hal ini dikarenakan bila memperoleh modal dari utang ataupun menerbitkan saham baru, 
mencerminkan bahwa perusahaan tidak mampu memenuhi kebutuhannya. Investor akan merespon negatif bila perusahaan memperoleh dana modal dari utang maupun penerbitan saham baru, sehingga lebih baik memperoleh modal dari internal perusahaan. Walaupun demikian, sesuai dengan signaling theory yang menjelaskan bahwa informasi mengenai tinggi rendahnya leverage mempengaruhi volatilitas harga saham perusahaan. Semakin tinggi nilai utang (debt) dibandingkan ekuitas, semakin memberikan sinyal buruk bagi investor. Berdasarkan pernyataan tersebut maka dapat dirumuskan hipotesis sebagai berikut:

H2 : Leverage berpengaruh positif terhadap volatilitas harga saham.

\section{Pengaruh Kebijakan Dividen Terhadap Volatilitas Harga Saham}

Menurut (Sartono, 2014:281) kebijakan dividen adalah keputusan apakah laba yang diperoleh perusahaan akan dibagikan kepada pemegang saham sebagai dividen atau akan ditahan dalam bentuk laba ditahan yang nantinya digunakan untuk berinvestasi dimasa mendatang. Indikator yang digunakan untuk mengukur kebijakan dividen pada penelitian ini adalah dividend payout ratio. Informasi tentang kebijakan dividen berhubungan dengan teori sinyal, karena informasi tersebut memberikan sinyal kepada investor tentang kinerja perusahaan dalam jangka panjang dan menarik minat investor untuk menanamkan dananya pada saham tersebut, sehingga permintaan akan saham naik dan pada akhirnya menyebabkan nilai saham juga akan naik. Hal tersebut mengindikasikan bahwa semakin besar pembayaran dividen, semakin kuat sinyal profitabilitas perusahaan, sehingga mengurangi risiko investor dalam berinvestasi dan rendahnya volatilitas harga saham. Berdasarkan pernyataan tersebut maka dapat dirumuskan hipotesis sebagai berikut:

H3 : Kebijakan dividen berpengaruh negatif terhadap volatilitas harga saham.

\section{METODE PENELITIAN}

\section{Jenis Penelitian}

Penelitian ini termasuk kategori penelitian kuantitatif, karena penelitian ini menggunakan pendekatan-pendekatan yang bersifat empiris kuantitatif untuk mengumpulkan, menganalisa, dan menyajikan data beserta hasil penelitiannya. Dalam penelitian kuantitatif terdapat beberapa metode penelitian, salah satu diantaranya adalah yang diaplikasikan dalam penelitian ini, yaitu metode penelitian asosiatif. Metode tersebut digunakan karena penelitian ini bertujuan mengetahui pengaruh atau hubungan antara dua variabel atau lebih.

\section{Populasi dan Sampel}

Populasi adalah wilayah generalisasi yang terdiri atas: obyek/ subyek yang mempunyai kualitas dan karakteristik tertentu yang ditetapkan oleh peneliti untuk dipelajari dan kemudian ditarik kesimpulannya (Sugiyono, 2007:115). Populasi dari penelitian ini adalah 45 perusahaan yang terdaftar dalam indeks LQ45 di Bursa Efek Indonesia periode 2016-2018, dimana peneliti ingin meneliti lebih dalam tentang volatilitas harga saham yang dipengaruhi oleh volume perdagangan saham, leverage, dan kebijakan dividen perusahaan tersebut, yang berasal dari Laporan Keuangan Tahunan periode 2016-2018.

Sedangkan untuk sampeldalam penelitian ini adalah sebagian dari populasi. Populasi pada dasarnya adalah objek yang akan diteliti, adapun yang akan dijadikan populasi dalam penelitian ini adalah data perusahaan perbankan yang terdaftar di Bursa Efek Indonesia. 
Sampel dipilih dengan metode purposive sampling, dengan harapan penelitian mendapatkan informasi dari kelompok sasaran spesifik (Sekaran, 2003). Kriteria-kriteria yang digunakan dalam penelitian sampel adalah:

1. Perusahaan yang termasuk dalam indeks LQ45 periode 2016-2018 secara terus menerus.

2. Perusahaan LQ45 yang laporan keuangannya dinyatakan dalam mata uang Rupiah.

3. Perusahaan LQ45 yang konsisten membagikan dividen selama tahun 2016-2018.

4. Perusahaan LQ45 yang tidak melakukan stock split selama periode 2016-2018.

\section{Pengukuran Variabel}

Variabel terikat pada penelitian ini adalah volatilitas harga saham. Volatilitas merupakan pengukuran statistik untuk fluktuasi harga selama periode tertentu.Ukuran tersebut menunjukkan penurunan dan peningkatan harga dalam jangka pendek.Rumus yang digunakan untuk mengukur volatilitas harga saham sesuai dengan penelitian yang dilakukan oleh Silvio J. C et al. (2019) adalah sebagai berikut:

$\sigma i, \mathrm{t}=\sqrt{\frac{H i, t-L i, t}{\left(\frac{H i, t+L i, t}{2}\right)^{2}}}$

Keterangan :

$\sigma \mathrm{i} ; \mathrm{t} \quad=$ Volatilitas harga saham i pada tahun $\mathrm{t}$

$\mathrm{Hi}, \mathrm{t} \quad=$ Harga saham $\mathrm{i}$ tertinggi pada tahun $\mathrm{t}$

Li,t = Harga saham $\mathrm{i}$ terendah pada tahun $\mathrm{t}$

Dalam Penelitian ini variabel bebas (independent) yang digunakan oleh penulis adalah Volume Perdagangan Saham (X1), Leverage (X2), dan Proporsi Dewan Kebijakan Dividen (X3).

Volume Perdagangan Saham

Volume perdagangan saham bisa diartikan sebagai jumlah transaksi saham yang diperdagangkan pada periode tertentu di bursa saham. Volume perdagangan saham diproksikan dengan log natural saham yang diperdagangkan. Secara matematis volume perdagangan saham dirumuskan sesuai dengan penelitian Silviana \& Sista (2019), yaitu sebagai berikut:

VP = Log natural (Tradeable Shares)

Leverage

Leverage adalah kemampuan perusahaan dalam memenuhi kewajiban jangka pendek maupun jangka panjang atau dengan kata lain mengukur seberapa besar perusahaan dibiayai dengan utang (Wiagustini, 2014:85). Leverage diproksikan dengan Debt to Equity Ratio (DER).Rumus debt to equity ratio sesuai dengan penelitian Silviana \& Sista (2019), yaitu sebagai berikut:

$\mathrm{DER}=\frac{\text { TOTAL DEBT }}{\text { TOTAL EQUITY }}$ 
Kebijakan Dividen

Kebijakan dividen merupakan keputusan perusahaan mengenai pembagian laba kepada pemegang saham sebagai dividen atau penahanan laba berupa laba ditahan untuk berinvestasi di masa datang (Sartono, 2014:281).Kebijakan dividen diproksikan dengan dividend payout ratio.Dividend payout ratio merupakan perbandingan antara dividen per lembar saham dengan laba per lembar saham.Rumus dividen payout ratio sesuai dengan penelitian Silviana \& Sista (2019), adalah sebagai berikut:

DPR $=\frac{\text { DIVIDEND PER SHARE }}{\text { EARNING PER SHARE }}$

\section{Teknik Analisis}

Dalam penelitian ini, peneliti menggunakan analisis pengaruh yaitu analisis regresi linier berganda. Regresi berganda merupakan pengembangan dari regresi linier sederhana yaitu sama-sama alat yang dapat digunakan untuk melakukan prediksi permintaan di masa yang akan datang, berdasarkan data masa lalu atau untuk mengetahui pengaruh satu atau lebih variabel bebas terhadap satu variabel terikat. Perbedaan penerapan metode ini hanya terletak pada jumlah variabel bebas yang digunakan. Penerapan metode regresi berganda jumlah variabel bebas yang digunakan lebih dari satu yang mempengaruhi satu variabel terikat. Adapun persamaannya adalah sebagai berikut:

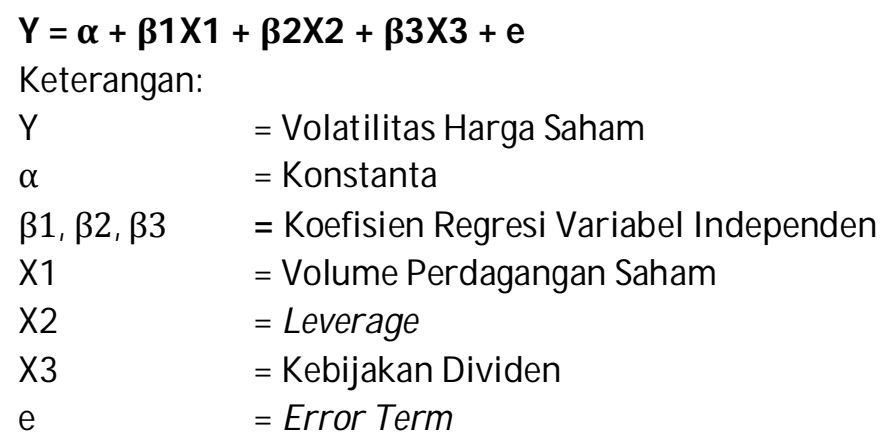

\section{HASIL DAN PEMBAHASAN}

Setelah menyajikan data penelitian, tahap selanjutnya yang dilakukan oleh peneliti adalah menganalisa dan menginterprestasikan data dengan menggunakan metode analisis yang telah dipilih.

\section{Statistik Deskriptif}

Analisis statistik deskriptif digunakan untuk memberikan deskripsi tentang data setiap variabel-variabel penelitian yang digunakan di dalam penelitian ini. Data tersebut meliputi jumlah data, nilai minimum, nilai maksimum, nilai rata-rata (mean), dan standar deviasi. Penelitian ini menggunakan variabel Volume Perdagangan Saham (X1), Leverage (X2)dan Kebijakan Dividen (X3) sebagai variabel independen, serta Volatilitas Harga Saham (Y) sebagai variabel dependen. Pada bagian ini akan disajikan deskripsi data yang diperoleh dari data yang telah diolah dengan program SPSS (Statistical Package for Social Science) Version 26 For Windows meliputi tabel distribusi frekuensi dan histogram dari masing-masing variabel. 


\section{Tabel 1}

Statistik Deskriptif

\begin{tabular}{lrrrrr}
\hline & N & \multicolumn{1}{c}{ MIN } & \multicolumn{1}{c}{ MAX } & \multicolumn{1}{c}{ M EAN } & \multicolumn{1}{c}{ SD } \\
\hline Dividend Payout Ratio & 54 &, 08 & 2,24 &, 4867 &, 38828 \\
Debt to Equity Ratio & 54 &, 15 & 11,06 & 20609 & 257589 \\
Volume Perdagangan & 54 & 192448 & 241408 & 21901944 & 12268854 \\
Volatilitas Harga Saham & 54 &, 0018 &, 0326 &, 010161 &, 0064565 \\
\hline
\end{tabular}

Sumber: Data diolah SPSS Versi 26

Berdasarkan tabel 1 diketahui bahwa jumlah sampel data dalam penelitian ini sebanyak 54 sampel data.Secara umum seluruh variabel yang diteliti menunjukkan nilai standar deviasi dibawah nilai rata-ratanya, artinya penyebaran nilai masing-masing variabel relatif kecil dibandingkan nilai rata-ratanya (kecuali leverage yang diproksikan dengan debt to equity ratio). Sedangkan secara rinci deskripsi masing-masing variabel dapat dijelaskan sebagai berikut:

Data kebijakan dividen yang diproksikan dengan dividend payout ratio terendah (minimum) adalah sebesar 0,08 milik perusahaan Bank Central Asia Tbk. pada tahun 2016 dan 2018, sedangkan nilai tertinggi (maksimum) adalah sebesar 2,24 milik Indocement Tunggal Prakarsa Tbk. pada tahun 2018. Nilai rata - rata (mean) adalah sebesar 0,4867 yang berarti rata-rata kebijakan dividen yang diambil oleh perusahaan LQ45 tahun 2016-2018 adalah sebesar $48,67 \%$ dari jumlah earning yang diperoleh perusahaan per tahundan nilai standar deviasinya adalah sebesar 0,38828.

Data leverage yang diproksikan dengan debt to equity ratioterendah (minimum) adalah sebesar 0,15milik Indocement Tunggal Prakarsa Tbk.tahun 2016 sedangkan nilai tertinggi (maksimum) adalah sebesar 11,06 milik Bank Tabungan Negara Tbk. tahun 2018. Nilai rata rata (mean) adalah sebesar 2,0609 yang menunjukkan bahwa rata-rata tingkat jumlah hutang sebesar 206\% cukup tinggi bila dipersentasikan dengan jumlah ekuitas pada perusahaan LQ45 tahun 2016-2018 dan nilai standar deviasinya adalah sebesar 2,57589.

Data volume perdagangan saham yang sudah ditransformasikan dengan log natural volume perdagangan saham terendah (minimum) adalah sebesar 19,2448milik Sawit Sumbermas Sarana Tbk tahun 2018. Sedangkan nilai tertinggi (maksimum) adalah sebesar 24,1408milik Telekomunikasi Indonesia Tbk.tahun 2016. Nilai rata-rata (mean) adalah sebesar 21,901944dan nilai standar deviasinya adalah sebesar 1,2268854.

Data volatilitas harga sahamterendah (minimum) adalah sebesar 0,0018 milik Gudang Garam Tbk. tahun 2018. Sedangkan nilai tertinggi (maksimum) adalah 0,0326 milikAKR Corporindo Tbk tahun 2016. Nilai rata-rata (mean) adalah sebesar 0,010161dan nilai standar deviasinya adalah sebesar 0,0064565.

\section{Uji Regresi Linier Berganda}

Analisis ini digunakan untuk mengetahui hubungan antara variabel bebas dengan variabel tetikat dengan menggunakan persamaan regresi estimasi. Hasil analisis regresi linier berganda dapat dilihat pada tabel 2 dibawah ini:

Uji Kecocokan Model

Uji statistik F pada dasarnya menunjukkan apakah semua variabel independen yang dimasukkan dalam model regresi tersebut layak digunakan untuk memprediksi variabel dependen. Dari tabel ANOVA atau $f$ test dapat diketahui bahwa nilai $f$ hitung sebesar 
2,982lebih besar dari t tabel sebesar 2,79 dan nilai signifikansi 0,04 lebih kecil dari 0,05 atau $5 \%$ maka dapat disimpulkan bahwa model yang dibentuk dalam regresi ini dapat dikatakan layak dan dapat memprediksi variabel dependen. Koefisien determinasi ( $\mathrm{R}^{2}$ atau $\mathrm{R}$ Square) dilakukan untuk mendeteksi seberapa jauh kemampuan model dalam menerangkan variasi variabel dependen. Nilai $\mathrm{R}^{2}$ yang kecil berarti kemampuan variabel-variabel independen dalam menjelaskan variabel dependen amat terbatas. Sebaliknya, nilai $\mathrm{R}^{2}$ yang mendekati satu menandakan variabel-variabel independen memberikan hampir semua informasi yang dibutuhkan untuk memprediksi variasi variabel dependen.

Tabel 2.

Hasil Analisis Regresi Linier Berganda

\begin{tabular}{lrrrrr}
\hline & B & $\begin{array}{c}\text { Std. } \\
\text { Error }\end{array}$ & Beta & t & Sig. \\
\hline (Constant) &,- 022 &, 016 & & $-1,345$ &, 185 \\
Dividend Payout Ratio &,- 003 &, 002 &,- 204 & $-1,420$ &, 162 \\
Debt to Equity Ratio &, 000 &, 000 &,- 081 &,- 584 &, 562 \\
Volume Perdagangan Saham &, 002 &, 001 &, 295 & 2,145 &, 037 \\
F-Statistics & 2,982 &, & & & \\
Adj. R Square &, 101 & & & & \\
\hline
\end{tabular}

Sumber : Data olahan SPSSVersi 26

Volume Perdagangan Saham memiliki nilai t hitung sebesar 2,145 yang dimana nilai t hitung lebih besar dari nilai t tabel sebesar 2,009 dan nilai signifikansi sebesar 0,037 yang dimana nilai signifikansi tersebut lebih kecil dari 0,05, sehingga H1 diterima. Kesimpulannya adalah variabel Volume Perdagangan Saham memiliki pengaruh positif terhadap Volatilitas Harga Saham. Oleh karena itu, hipotesis pertama yang menyatakan Volume Perdagangan Saham berpengaruh positif terhadap Volatilitas Harga Saham didukung hasil penelitian ini karena dalam hasil penelitian ini Volume Perdagangan Saham berpengaruh positif terhadap Volatilitas Harga Saham.

Leverage memiliki nilai t hitung sebesar -0,584yang dimana nilai t hitung lebih besar dari nilai t tabel sebesar -2,009 dan nilai signifikansi sebesar 0,562 dimana nilai signifikansi tersebut lebih dari 0,05, sehingga H2 ditolak. Kesimpulannya adalah variabel Leverage tidakberpengaruh terhadap Volatilitas Harga Saham.Oleh karena itu, hipotesis kedua yang menyatakan Leverage berpengaruh positif terhadap Volatilitas Harga Saham tidak didukung.

Kebijakan Dividen memiliki nilai t hitung sebesar -1,420 yang dimana nilai t hitung lebih besar dari nilai t tabel sebesar -2,009dan nilai signifikansi sebesar 0,162 dimana nilai signifikansi tersebut lebih dari 0,05, sehingga H3 ditolak. Kesimpulannya adalah variabel Kebijakan Dividen tidak berpengaruh terhadap Volatilitas Harga Saham.Oleh karena itu, hipotesis ketiga yang menyatakan Kebijakan Dividen berpengaruh negatif terhadap Volatilitas Harga Saham tidak didukung.

\section{Pembahasan}

Hasil pengujian menunjukkan bahwa Volume Perdagangan Saham terbukti berpengaruh positif terhadap Volatilitas Harga Saham dimana Volume Perdagangan Saham memiliki nilai t hitung sebesar 2,145 yang dimana nilai t hitung lebih besar dari nilai t tabel sebesar 2,009 dan nilai signifikansi sebesar 0,037 yang berarti nilai signifikansi tersebut lebih kecil dari 0,05 . Dengan demikian hasil ini sesuai dengan hipotesis penelitian yang diajukan yaitu bahwa 
Volume Perdagangan Saham memiliki pengaruh positifterhadapVolatilitas harga Saham, maka hipotesis pertama diterima.Jadi semakin besar Volume Perdagangan Saham maka Volatilitas Harga Saham juga cenderung meningkat.Hal ini dapat terjadi sebabinvestor merespon berbeda informasi dari perusahaan yang mampu mempengaruhi fluktuasi harga saham, sesuai dengan teori sinyal.Dimana volume perdagangan saham dapat menunjukkan reaksi pasar terhadap respon dari investor tersebut. Dengan demikian informasi yang merupakan sinyal dari perusahaan dapat mempengaruhi volatilitas harga saham yang terlihat dari volume perdagangan atau seringnya saham tersebut diperjualbelikan pada bursa.

Dewi dan Suaryana (2016) menjelaskan bahwa volume perdagangan saham mencerminkan informasi yang diterima oleh pelaku pasar. Apabila tidak ada informasi mengenai saham, maka investor lebih cenderung untuk tetap memegang saham mereka sehingga volume perdagangan saham menurun akibat sedikitnya saham yang dijual, hal ini akan mengakibatkan volatilitas harga saham menjadi rendah. Informasi yang diperoleh mengakibatkan para pelaku pasar akan terus melakukan perbaikan terhadap interpretasi informasi baik dengan membeli, menjual, atau diam mengakibatkan harga saham akan bergerak, dengan kata lain volatilitas saham dipengaruhi oleh interpretasi informasi yang dicerminkan oleh volume perdagangan saham.Hasil penelitian ini juga diperkuat dengan hasil penelitian Dewi\&Suaryana (2016) dan Nasir, dkk(2018) bahwa Volume Perdagangan Saham berpengaruh positif terhadap Volatilitas Harga Saham. Namun tidak mendukung hasil penelitian Andiani \& Gayatri (2018) dan Dewi \& Paramita (2019) yang menunjukkan bahwa Volume Perdagangan Saham tidak memiliki pengaruh terhadap Volatilitas Harga Saham dan tidak mendukung hasil penelitian Priana \& Muliartha (2017) yang menunjukkan bahwa Volume Perdagangan Saham memiliki pengaruh negatif terhadap Volatilitas Harga Saham.

Hipotesis 2. Hasil pengujian menunjukkan bahwa Leverage tidak berpengaruh terhadap Volatilitas Harga Saham dimanaLeverage memiliki nilai t hitung sebesar -0,584yang dimana nilai t hitung lebih besar dari nilai t tabel sebesar -2,009 dan nilai signifikansi sebesar 0,562 yang berarti nilai signifikansi tersebut lebih dari 0,05. Hasil ini tidak mendukung hipotesis kedua yang diajukan yaitu bahwa Leverage memiliki pengaruh positifterhadapVolatilitas Harga Saham, oleh karena itu hipotesis kedua ditolak.

Alasan yang mendukung tidak adanya pengaruh leverage terhadap volatilitas harga saham dikarenakan perusahaan mampu memanfaatkan dana hutang yang dimiliki untuk memaksimalkan kegiatan operasional. Meskipun nilai debt to equity perusahaan tersebut tinggi, akan tetapi perusahaan dapat meningkatkan produktifitasnya. Dengan demikian, tinggi rendahnya leverage perusahaan belum tentu berpengaruh terhadap volatilitas harga sahamnya. Hal ini mengindikasikan bahwa para investor tidak menggunakan DER sebagai ukuran kinerja pasar untuk memprediksi harga saham dipasar modal. Investor tidak selalu melihat ketergantungan perusahaan terhadap hutang yang harus diperhatikan dalam pengambilan keputusan investasi namun investor lebih memperhatikan seberapa besar kemampuan perusahaan dalam menghasilkan pendapatan. Tinggi rendahnya rasio DER tidak selalu menimbulkan reaksi terhadap pergerakan/volatilitas harga saham. DER tidak dapat memberikan informasi kepada investor apakah kinerja perusahaan tersebut baik atau buruk. Perusahaan yang mempunyai hutang banyak belum tentu kinerja perusahaannya buruk. Jika tingkat pengembalian dari penambahan hutang lebih tinggi dari tingkat bunganya, maka penambahan hutang memiliki efek financial yang menguntungkan (Priyo, 2010). Hasil penelitian ini juga sejalan dengan hasil penelitian Dewi \& Suaryana (2016), Dewi \& Paramita 
(2019), dan Selpiana \& Badjra (2018) bahwa Leverage tidak berpengaruh terhadap Volatilitas Harga Saham. Namun tidak mendukung hasil penelitian Marini \& Dewi (2019) yang menunjukkan bahwa Leverage memiliki pengaruh positif terhadap Volatilitas Harga Saham, serta tidak mendukung hasil penelitian Priana \& Muliartha (2017) yang menunjukkan bahwa Leverage memiliki pengaruh negatif terhadap Volatilitas Harga Saham.

Hipotesis 3. Hasil pengujian menunjukkan bahwa Kebijakan Dividen tidak berpengaruh terhadap Volatilitas Harga Saham dimana Kebijakan Dividen memiliki nilai t hitung sebesar 1,420 yang dimana nilai t hitung lebih besar dari nilai t tabel sebesar -2,009 dan nilai signifikansi sebesar 0,162 yang berarti nilai signifikansi tersebut lebih dari 0,05. Oleh karena itu, hipotesis ketiga yang menyatakan Kebijakan Dividen berpengaruh negatif terhadap Volatilitas Harga Saham ditolak.

Tanpa mempertimbangkan faktor lain yang mempengaruhi volatilitas harga saham, seharusnya perusahaan yang konsisten membagikan dividen akan menarik perhatian para investor. Perusahaan yang membagikan dividen menunjukkan bahwa perusahaan tersebut mampu untuk memenuhi kebutuhan dan kewajibannya secara finansial. Hal ini tentu saja akan memberikan rasa aman bagi para investor yang berinvestasi di perusahaan tersebut. Jika investor merasa aman, dana yang diinvestasikan atau ditanam di perusahaan tersebut tidak akan diambil, sehingga menyebabkan stabilnya harga saham di pasar modal atau dengan kata lain volatilitas harga saham akan turun. Tetapi, kebijakan dividen bukanlah satusatunya hal yang menjadi pertimbangan para investor dalam berinvestasi.

Banyak faktor-faktor lain yang mempengaruhi keputusan investor. Dalam hal ini, khususnya pada perusahaan LQ45, para investor tidak mendasarkan keputusan investasinya pada kebijakan dividen, sehingga tidak mempengaruhi volatilitas harga saham perusahaan LQ45. Dalam persamaan regresi yang digunakan dalam penelitian ini, variabel bebas hanya mampu menjelaskan pengaruh variabel bebas sebanyak 15,2\% terhadap variabel terikat. Sebanyak $84,8 \%$ inilah yang lebih dominan dalam mempengaruhi volatilitas harga saham, sehingga dalam penelitian ini kebijakan dividen tidak berpengaruh terhadap volatilitas harga saham. Hasil penelitian ini juga sejalan dengan hasil penelitian Nasir, dkk (2018) bahwa Leverage tidak berpengaruh terhadap Volatilitas Harga Saham. Namun tidak mendukung hasil penelitian Priana \& Muliartha (2017) yang menunjukkan bahwa Leverage memiliki pengaruh positif terhadap Volatilitas Harga Saham, serta tidak mendukung hasil penelitian Marini \& Dewi (2019), Dewi \& Paramita (2019), Camilleri, dkk (2019), dan Ahmad, dkk (2018) yang menunjukkan bahwa Kebijakan Dividen memiliki pengaruh negatif terhadap Volatilitas Harga Saham.

\section{KESIMPULAN}

Merujuk pada hasil penelitian mengenai "Pengaruh Volume Perdagangan Saham, Leverage, dan Kebijakan Dividen terhadap Volatilitas Harga Saham pada Perusahaan LQ45 yang terdaftar di Bursa Efek Indonesia," sebanyak 18 perusahaan yang secara konsisten terdaftar di indeks LQ45 serta memenuhi kriteria sampel dalam penelitian iniselama tiga tahun yaitu 2016-2018 terkumpul sebanyak 54 data sampel. Berdasarkan data yang telah dianalisis serta diolah menggunakan teknik analisis regresi berganda dengan bantuan program SPSS Version 26, maka dapat disimpulkan bahwa:

Pertama, volume Perdagangan Saham terbukti berpengaruh positif terhadap Volatilitas Harga SahamPerusahaan LQ45 yang terdaftar di Bursa Efek Indonesia. .Dengan demikian hipotesis pertama yang menyatakan Volume Perdagangan Saham berpengaruh positif 
terhadapVolatilitas Harga Saham diterima. Kedua, leverage tidak berpengaruh terhadap Volatilitas Harga Saham Perusahaan LQ45 yang terdaftar di Bursa Efek Indonesia. Dengan demikian hipotesis kedua yang menyatakan Leverage berpengaruh positif terhadap Volatilitas Harga Sahamditolak. Ketiga, kebijakan Dividen tidak berpengaruh terhadap Volatilitas Harga Saham Perusahaan LQ45 yang terdaftar di Bursa Efek Indonesia. Dengan demikian hipotesis ketiga yang menyatakan Kebijakan Dividen berpengaruh negatif terhadap Volatilitas Harga Saham ditolak.

Selanjutnya, berdasarkan pengalaman pada penelitian yang telah dilakukan, maka peneliti memberikan salah satu saran berkaitan dengan hasil penelitian ini, yakni bagi para investor yang sudah atau akan melakukan investasi, hasil penelitian ini diharapkan dapat berguna sebagai bahan pertimbangan dalam pengambilan keputusan investasi. Investor dapat memperhatikan volatilitas harga saham dalam menentukan langkah yang tepat saat mengambil keputusan investasi sehingga dapat memilih saham perusahaan yang tepat yang dapat memberikan capital gain. Investor juga sebaiknya lebih memperhatikan volume perdagangan saham dibandingkan leverageataukebijakan dividen jika ingin melakukan aktivitas investasi terhadap saham yang diperjualbelikan di bursa efek karena semakin tinggi volume perdagangan suatu saham, maka saham tersebut banyak diminati oleh investor lain yang berdampak pada meningkatnya volatilitas harga saham. Bagi perusahaan yang memiliki volatilitas harga saham tinggi, saham tersebut cocok untuk dijadikan investasi jangka pendek atau trading, Sebaliknya bagi perusahaan yang memiliki volatilitas harga saham rendah, saham tersebut cocok untuk dijadikan investasi jangka panjang.

\section{REFERENSI}

Ahmad, M. A., Alrjoub, A. M. S., \& Alrabba, H. M. (2018). The effect of dividend policy on stock price volatility: empirical evidence from amman stock exchange. Academy of Accounting and Financial Studies Journal, 22(2), 1-8.

Andiani, N. W. S., \& Gayatri, G. (2018). Pengaruh Volume Perdagangan Saham, Volatilitas Laba, Dividend Yield, dan Ukuran Perusahaan Pada Volatilitas Harga Saham. E-Jurnal Akuntansi, 24(3), 2148-2175.

Camilleri, S. J., Grima, L., \& Grima, S. (2019). The effect of dividend policy on share price volatility: An analysis of Mediterranean banks' stocks. Managerial Finance.

Dewi, N. M. A. K., \& Suaryana, I. G. N. A. (2016). Pengaruh volume perdagangan saham, leverage, dan tingkat suku bunga terhadap volatilitas harga saham. E-Jurnal Akuntansi, 17(2), 1112-1140.

Dewi, S., \& SISTA PARAMITA, R. A. (2019). Pengaruh Kebijakan Dividen, Volume Perdagangan, Earning Volatility, Leverage, dan Firm Size Terhadap Volatilitas Harga Saham Perusahaan LQ45. Jurnal Ilmu Manajemen (JIM), 7(3).

Fahmi, I. (2012). Manajemen Investasi: Teori dan Soal Jawab. Jakarta: Salemba Empat.

Harahap, S. S. (2009). Analisis Kritis atas Laporan Keuangan (Edisi Satu). Jakarta: PT. Raja Grafindo Persada.

Hartono, J. (2015). Teori Portofolio dan Analisis Investasi (Edisi Sepuluh). Yogyakarta: BPFE.

Husnan, S. \& Pudjiastuti, E. (2012). Dasar-Dasar Manajemen Keuangan (Edisi Enam). Yogyakarta: UPP STIMYKPN.

Imron, H.R., Fitri, R., \& Hendryadi, H. (2020). Pengaruh nilai tukar dan indeks pasar saham global terhadap indeks harga saham sektoral. INOVASI, 16(1), 11-20.

Jannah, R., \& Haridhi, M. (2016). Pengaruh Kebijakan Dividen, Earning Volatility, Dan Leverage Terhadap Volatilitas Harga Saham Pada Perusahaan Non-Financing Yang Terdaftar Di Bursa Efek Indonesia Tahun 2010-2014. Jurnal Ilmiah Mahasiswa Ekonomi Akuntansi, 1(1), 133-148. 
Madura, J. (2014). Financial Markets and Institutions (11th Edition). Boston: Cengage Learning

Marini, N. L. P. S., \& Dewi, S. K. S. (2019). Pengaruh Kebijakan Dividen, Leverage, Dan Ukuran Perusahaan Terhadap Volatilitas Harga Saham. E-Jurnal Manajemen, 8(10), 5887-5906.

Ouso, J. N. (2012). The effect of leverage on share prices at the Nairobi Securities Exchange (Doctoral dissertation).

Priana, I. W. K., \& RM, K. M. (2017). Pengaruh Volume Perdagangan Saham, Leverage, Dan Dividend Payout Ratio Pada Volatilitas Harga Saham. E-Jurnal Akuntansi, 20(1), 1-29.

Profilet, K. A. (2013). Dividend policy and stock price volatility in the US equity capital market.

Sari, E. M. (2019). Analisis Faktor-faktor yang Mempengaruhi Volatilitas Harga Saham pada Perusahaan yang Terdaftar di Bursa Efek Indonesia (Doctoral dissertation, Universitas Internasional Batam).(accessed 2 April 2020).

Selpiana, K. R., \& Badjra, I. B. (2018). Pengaruh Kebijakan Dividen, Nilai Tukar, Leverage, dan Firm Size Terhadap Volatilitas Harga Saham. E-Jurnal Manajemen Universitas Udayana, 7(3).

Tandelilin, E. (2010). Portofolio dan Investasi Teori dan Aplikasi (Edisi Satu). Yogyakarta: Kanisius.

Theresia, P., \& Arilyn, E. J. (2015). Pengaruh dividen, ukuran perusahaan, hutang jangka panjang, earning volatility, pertumbuhan aset, trading volume, dan kepemilikan manajerial terhadap volatilitas harga saham. Jurnal Bisnis dan Akuntansi, 17(2), 197204.

Wiagustini, N. L. P. (2014). Manajemen Keuangan. Denpasar: Udayana University Press

\title{
Declarations
}

\section{Funding}

The authors received no financial support for the research and publication of this article.

\section{Conflicts of interest/ Competing interests:}

The authors have no conflicts of interest to declare that are relevant to the content of this article.

\section{Data, Materials and/ or Code Availability:}

Data sharing is not applicable

\begin{abstract}
About the Authors
Mario Ascaryo Septyadi adalah salah seorang mahasiswa akuntansi strata satu yang telah lulus dengan predikat memuaskan dari Universitas Bunda Mulia dan saat ini telah bekerja sebagai Staf Pajak di Bank Mayapada International, Tbk (Mayapada Tower - Kuningan).

Theresia Hesti Bwarleling adalah seorang tenaga pengajar Prodi Akuntansi Fakultas Ilmu Sosial dan Humaniora Universitas Bunda Mulia dengan pengalaman mengajar yang didominasi di bagian akuntansi keuangan seperti Seminar Akuntansi Keuangan dan Lab. Akuntansi Keuangan dan Akuntansi Manajemen pada tingkat sarjana. Penulis memiliki ketertarikan pada penelitian atas berbagai bentuk penerapan konsep akuntansi keuangan serta relevansinya pada nilai pasar. Theresia Hesti Bwarleling dapat dihubungi di: tbwarleling@bundamulia.ac.id
\end{abstract}

\section{How to cite this Article}

Septyadi, M., \& Bwarleling, T. (2020). Pengaruh Volume Perdagangan Saham, Leverage, dan Kebijakan Dividen Terhadap Volatilitas Harga Saham. AKURASI: Jurnal Riset Akuntansi Dan Keuangan, 2(3), 149 162. Retrieved from https:/ / ejournal.imperiuminstitute.org/index.php/ AKURASI/ article/ view/ 251 